\title{
Evaluation of autolysis induced histologic alterations in skeletal muscle tissue of non-traditional meat animals
}

\author{
Leila KAIMBAYEVA $^{1 *}$ (D), Shynar KENENBAY², Daniyar ZHANTLEUOV ${ }^{3}$, Aigul TAYEVA ${ }^{4}$, \\ Nursulu AKHMETOVA ${ }^{4}$, Zhanar MEDEUBAYEVA ${ }^{4}$
}

\begin{abstract}
Raw meat is characterized by various natural cellular processes that lead to its chemical content alteration. The purpose of the present study is to evaluate autolysis induced histologic alterations in skeletal muscle tissue of cow elk. In this study the authors used skeletal muscle tissue of 2-year-old cow elk. The tissue was sampled from $\mathrm{m}$. quadriceps femoris. The study results showed that in 48 hours post mortem linear striation in muscle tissues was expressed. But 72 hours post mortem the integrity of muscle fibers degraded and they became inconsistently stained. The obtained data showed that post mortem alterations were characterized by significant degradation and separation of muscle fibers and nuclei and nuclear structures lysis.
\end{abstract}

Keywords: elk meat; post mortem aging; muscle fibers; nuclei lysis; sarcolemma.

Practical Application: Control about of autolysis induced histologic alterations in skeletal muscle tissue of cow elk.

\section{Introduction}

Meat and meat products are the most valuable nutritional products, so it is crucial not only to preserve their initial properties but also to improve them in the process of technological processing. Meat properties to certain extent depend on the tissues ratio, based on their chemical composition and structure, and the stability of meat properties determine the intensity of the possible alterations in nutritional value and safety of the product (Kaimbaeva \& Gurinovich, 2016; Malysheva \& Zhukov, 2015; Kaimbaeva, 2008; Kaimbaeva \& Uzakov, 2015; Malysheva \& Zhukov, 2013).

Composition complexity and meat properties diversity require a complex of analytical methods for objective and overall quality evaluation. Grade of freshness and maturity are the main criteria of meat freshness evaluation. These parameters will primarily determine organoleptic properties of processed meat products. Any meat intended for commercial distribution has to be fresh. Freshness is identified by organoleptic, chemical, microscopic and histologic studies of the carcass or its parts (Antipova et al., 2000). Meat properties improve after post-mortem aging. Muscle tissue softens and obtains pleasant smell and taste, fine texture and high moisture-holding capacity (Rogov et al., 2013; Nikiforova et al., 2011; Kudryashov, 2007).

One of the methods of meat freshness and degree of post-mortem aging evaluation is histologic study. It is performed with the help of section cutting equipment "Microtom" that allows the specialists to obtain frozen section cuts of animal or plant tissues for microscopic studies (Standard of Organisation, 2013; Cocolin et al., 2011; Damez \& Clerjon, 2008; Dutson et al., 1980;
Dwinger et al., 2008; Hope-Jones et al., 2010; Krause et al., 2011; Cheret et al., 2007). Histologic method is based on identification of tissue structure alterations during its degradation. Meat freshness degree is identified by the state of nuclear structures and striated muscle fibers. Post-mortem aging degree is measured by microstructural meat characteristics alterations. The purpose of the present study was to evaluate autolysis induced histologic alterations in skeletal muscle tissue of cow elk.

\section{Materials and methods}

Samples of 2-year-old cow elk muscle tissue were taken from $\mathrm{m}$. quadriceps femoris right after dressing of the carcass. Further, they were packed and left for aging at $2-4^{\circ} \mathrm{C}$. Animals slaughtering was performed at elk breeding farm in Katon-Karagaiskiy subregion in Eastern Kazakhstan region; the animals were exsanguinated after stunning $(50 \mathrm{~Hz})$. Zero point of diagrams that represented the studied parameters alterations was taken as 2-3 hours post mortem and after carcasses dressing, when the meat temperature was $35-36{ }^{\circ} \mathrm{C}$ and it was considered to be slaughterwarm meat. The samples were taken 30 minutes, 24, 48, 72, 96 and 120 hours post mortem.

Histologic studies were performed in accordance with the standard 00493184-001-2013 "Elk meat. Histologic study" (Standard of Organisation, 2013). Histologic slides were obtained by conventional method: the samples were fixed in formalin for 7 days, dehydrated and fixed in ascending grades of in alcohol solutions (from $50 \%$ to $100 \%$ ) with $4-6 \%$ intervals and 24 -hour 
duration of each study stage, and imbedded in paraffin for 6-10 days with $8-12 \%$ part by weight for $3-5$ days. The sectioning of tissue samples for histologic slides was done by the described microtome with further hematoxylin and eosin staining and embalming in fir balsam. The obtained preparations were studied under Biolam R1U4 microscope at x13 by 3.2-40 lens. Further, the evaluation of microscopic alterations in normal and post-mortem conditions was performed by means of micro-net and micro-ruler (Standard of Organisation, 2013).

\section{Results and discussion}

Evaluation of autolysis induced histologic alterations in 2-year-old cow elk muscle tissue was performed. The results of cow elk skeletal muscle tissue histologic study showed that 30 minutes' post mortem muscle fibers were coarsely granulous, medium wide, alternate cross striated and had intense red color. The slide featured peripherally situated multiple bean-shaped nuclei. Their structure was clearly identified and the staining was even (Figure 1).
24 hours post mortem insignificant deformation of muscle fibers was observed. The fibers were red and longitudinally disposed. The features seen were peripherally stained multiple bean-shaped nuclei with clear structure shape (Figure 2).

48 hours post mortem longitudinal straining was well observed in muscle fibers. The features seen were insignificant deformations of interfiber space and disturbance of fibers alternate straining. Bean-shaped nuclei were located beyond the damaged cell membrane (sarcolemma) in intercellular space. Their structure was not clearly shaped and the staining was uneven (Figure 3).

72 hours post mortem consistency of cow elk muscle fibers was disturbed, the staining was not even. The majority of muscle fibers were fragmented and, as a result, degraded into segments. The features seen were single peripherally located bean-shaped nuclei with enlightened areas in their central part (Figure 4).

96 hours post mortem muscles fibers were thinned. Multiple destructive alterations in muscle tissues were characterized by

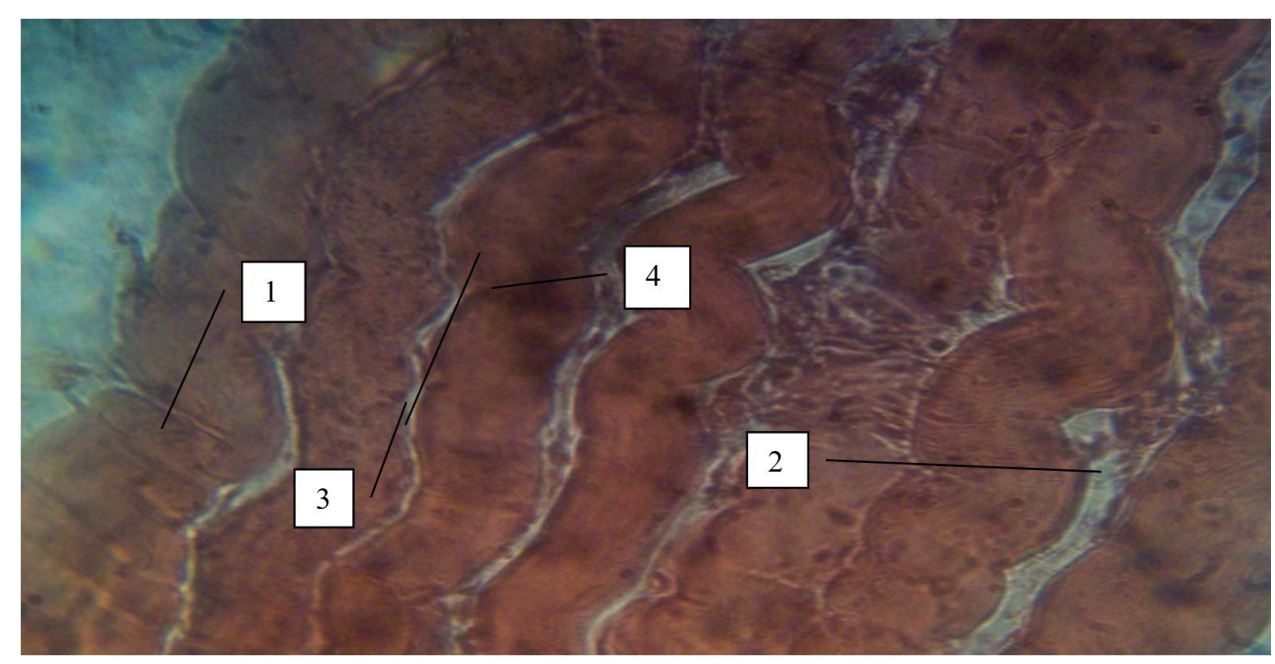

Figure 1. Longitudinal section of 2 year old cow elk skeletal muscle tissue 30 minutes post mortem (magnification $x 40 \times$ lens 7 ): 1 - muscle fibers; 2 - connective tissue; 3 - muscle fiber nuclei; 4 - cross-bridges.

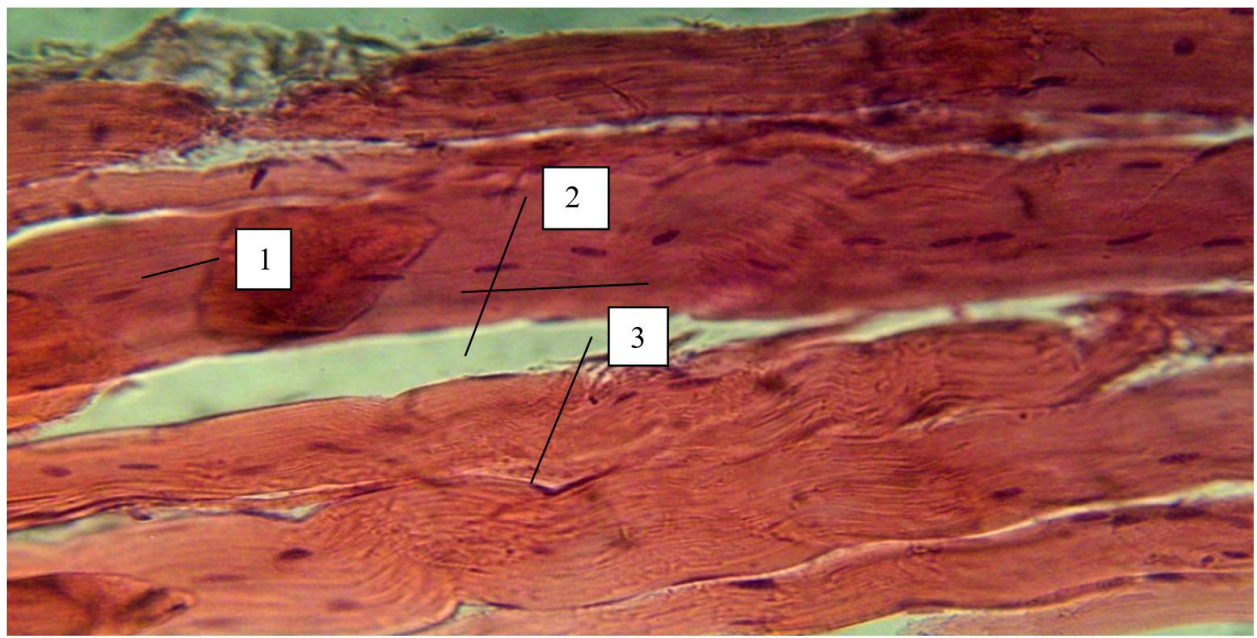

Figure 2. Longitudinal section of 2-year-old cow elk skeletal muscle tissue 24 hours post mortem (magnification x40 x lens 7 ): 1 - muscle fibers; 2 - connective tissue; 3 - muscle fiber nuclei. 
fibers separation and cross breaks. The features seen were depleted and flattened nuclei, primarily located beyond sarcolemma (Figure 5) (Panero et al., 2018; Andrade et al., 2018).

120 hours post mortem samples featured single fragments of pale muscle tissue in the field of vision due to low sensitivity of fibers to oxyphyle staining. Very few nuclei were observed (Figure 6) (Malysheva and Zhukov, 2013; Kurchaeva et al., 2018; Farias et al., 2018).

Quantitative studies of 2-year-old cow elk skeletal muscle tissue samples showed that maximal muscle fibers diameter was
$66.2 \pm 0.4 \mu \mathrm{m}(\mathrm{P} \leq 0.001)$, endomysium diameter was $6.6 \pm 0.02 \mu \mathrm{m}$ $(\mathrm{P} \leq 0.05)$, perimysium diameter was $16.2 \pm 0.02 \mu \mathrm{m}(\mathrm{p} \leq 0.01)$. Muscle fibers nuclei diameter was $17.7 \pm 0.02 \mu \mathrm{m}(\mathrm{P} \leq 0.01)$ and similar to the diameter in the samples, obtained 30 minutes' post mortem (Figure 7).

24 hours post mortem cow elk muscle fibers diameter reduced by $5.0 \pm 001 \mu \mathrm{m}(\mathrm{P} \leq 0.005)$, endomysium diameter - by $0.5 \pm 0.01 \mu \mathrm{m}$ $(\mathrm{P} \leq 0.005)$, perimysium diameter - by $0.9 \pm 0.01 \mu \mathrm{m}(\mathrm{P} \leq 0.005)$ and muscle fibers nuclei diameter - by $1.2 \pm 0.01 \mu \mathrm{m}(\mathrm{P} \leq 0.005)$. Muscle fibers degradation and nuclei lysis, that resulted in

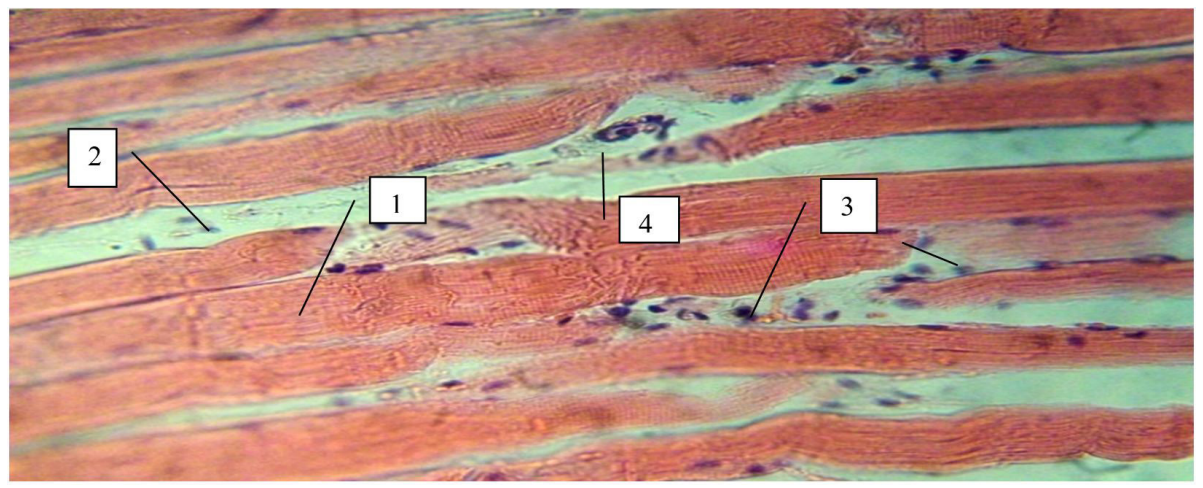

Figure 3. Longitudinal section of 2-year-old cow elk skeletal muscle tissue 48 hours post mortem (magnification x40 x lens 7): 1 - muscle fibers; 2 - connective tissue; 3 - muscle fiber nuclei; 4 - micro deformations of muscular fibers.

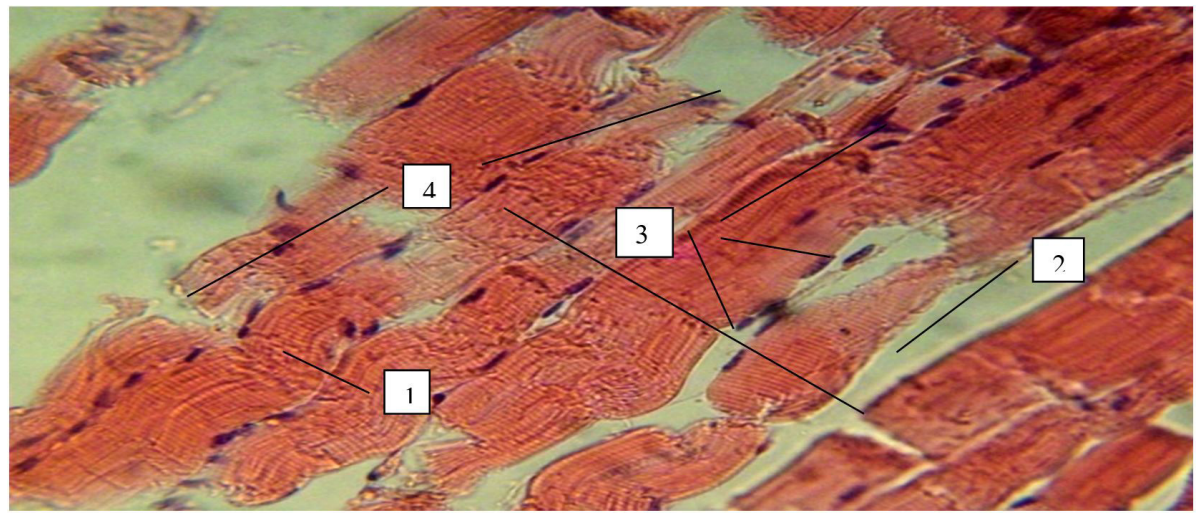

Figure 4. Longitudinal section of 2-year-old cow elk skeletal muscle tissue 72 hours post mortem (magnification x40 x lens 7 ): 1 - muscle fibers; 2 - connective tissue; 3 - muscle fiber nuclei; 4 - segmented muscle tissue fibers.

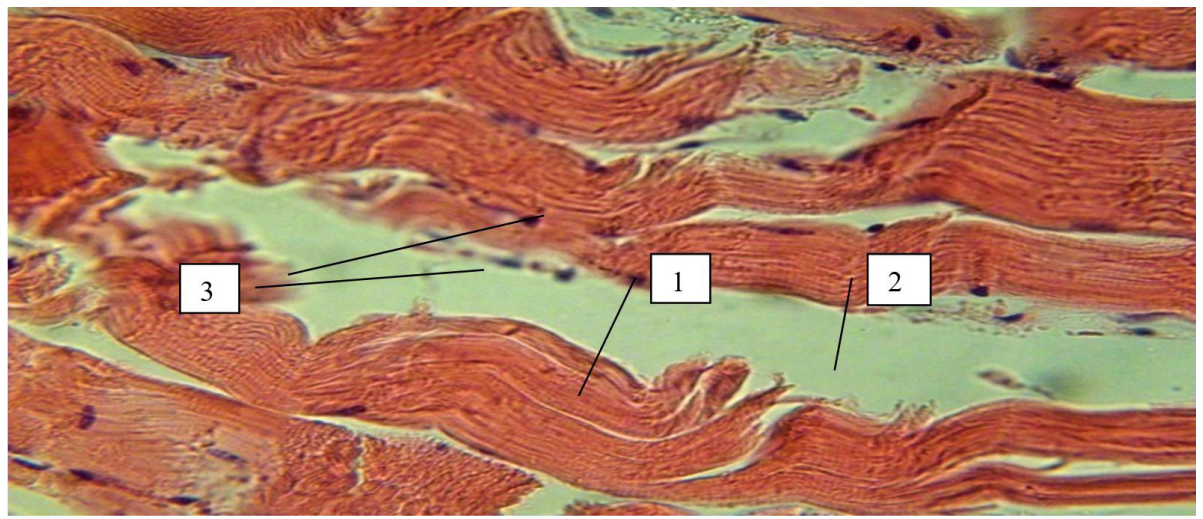

Figure 5. Longitudinal section of 2-year-old cow elk skeletal muscle tissue 96 hours post mortem (magnification x40 x lens 7 ): 1 - muscle tissue separation; 2 - connective tissue; 3 - muscle fibers nuclei. 


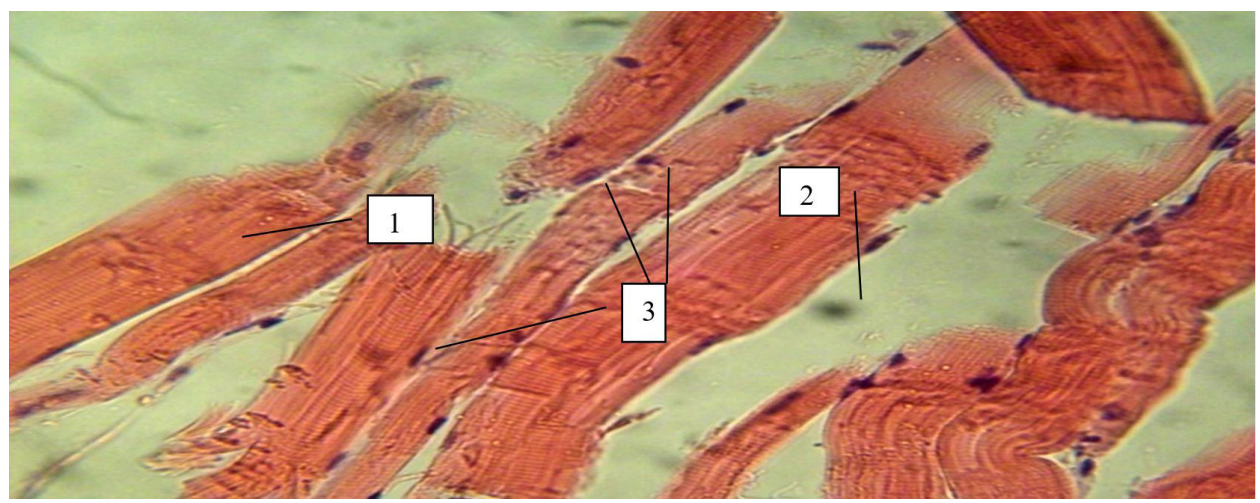

Figure 6. Longitudinal section of 2 year old cow elk skeletal muscle tissue 120 hours post mortem (magnification x40 x lens 7 ): 1 - muscle fiber segments; 2 - connective tissue; 3 - muscle fibers nuclei.

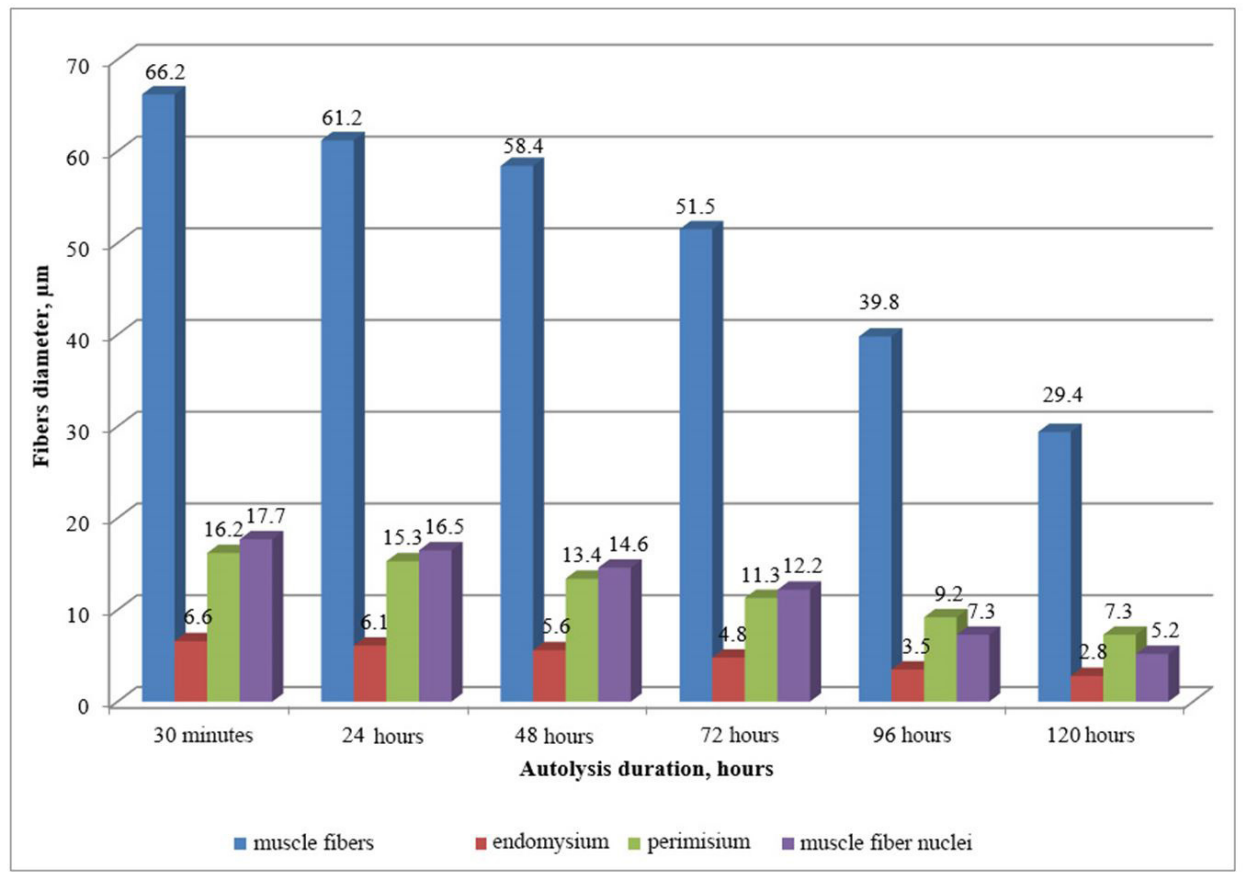

Figure 7. Influence of cow elk skeletal muscle fibers diameter on autolysis duration.

autolytic alterations, were performed by endogenous enzymes. Quantitative parameters altered as well. Thus, 48 hours post mortem muscle fibers diameter reduced by $7.8 \pm 0.02 \mu \mathrm{m}$ $(\mathrm{P} \leq 0.05)$, endomysium diameter - by $1.0 \pm 0.02 \mu \mathrm{m}(\mathrm{P} \leq 0.05)$, perimysium diameter - by $2.8 \pm 0.02 \mu \mathrm{m}(\mathrm{P} \leq 0.05)$, and muscle fibers nuclei diameter - by $3.1 \pm 0.02 \mu \mathrm{m}(\mathrm{P} \leq 0.05)$.

Further, during 72 hours post mortem diameter of muscle fibers, endomysium, perimysium and fibers nuclei reduced by $14.7 \pm 0.02 \mu \mathrm{m}(\mathrm{P} \leq 0.01) ; 3.8 \pm 0.02 \mu \mathrm{m}(\mathrm{P} \leq 0.05)$; $4.9 \pm 0.02 \mu \mathrm{m}(\mathrm{P} \leq 0.05)$ and $10.4 \pm 0.02 \mu \mathrm{m}(\mathrm{P} \leq 0.05)$, respectively. 96 hours post mortem the obtained parameters values decreased by 1.6, 2.3, 1.7 and 2.4 times, respectively. The most significant alteration of the studied parameters was observed 120 hours post mortem. Thus, muscle fibers diameter reduced by 2.3 times, endomysium diameter - by 2.4 times, perimysium diameter - by 2.2 times and muscle fibers nuclei - by 3.4 times.

\section{Conclusion}

The authors studied meat properties that depended on the ratio of tissues, structures and chemical composition. Material of the study was cow elk skeletal muscle tissue. The tissue samples were taken 30 minutes, 24, 48, 72, 96 and 120 hours post mortem. Histologic slides were prepared by conventional method based on fixing the section cuts in formalin for 7 hours. It was established that 30 minutes post mortem muscle tissues had good striation and intense color. 120 hours post mortem muscle fibers diameter reduced by 2.3 times and muscle tissue fibers nuclei - by 3.4 times.

Based on the obtained study results, the authors concluded that post mortem alterations in 2-year-old cow elk skeletal muscle tissue were characterized by multiple separation and degradation of muscle fibers, nuclei and nuclear structures lysis. 
These processes resulted in irreversible destructive alterations in muscle tissue. Hence, the mechanisms of autolytic processes influence on both morphological composition of muscle tissue and storage time of raw elk meat.

\section{References}

Andrade, F. P. D., Alves, T. W. B., Lira, M. H. P. D., Menezes, M. E. D. S., \& Lima, I. O. (2018). Alternaria spp. in foods: mycotoxins, cellular damage and possible health risk. Periódico Tchê Química, 15(30), 19-26.

Antipova, L. V., Glotova, I. A., \& Zharinov, A. I. (2000). Meat and meat products test methods. Voronezh: Voronezh State Technological Academy Press.

Cheret, R., Delbarreladrat, C., Lamballerieanton, M., \& Verrezbagnis, V. (2007). Calpain and cathepsin activities in postmortem fish and meat muscles. Food Chemistry, 101(4), 1474-1479. http://dx.doi. org/10.1016/j.foodchem.2006.04.023.

Cocolin, L., Dolci, P., \& Rantsiou, K. (2011). Biodiversity and dynamics of meat fermentations: The contribution of molecular methods for a better comprehension of a complex ecosystem. Meat Science, 89(3), 296-302. http://dx.doi.org/10.1016/j.meatsci.2011.04.011. PMid:21555189.

Damez, J. L., \& Clerjon, S. (2008). Meat quality assessment using biophysical methods related to meat structure. Meat Science, 80(1), 132-149. http://dx.doi.org/10.1016/j.meatsci.2008.05.039. PMid:22063178.

Dutson, J. R., Smith, G. C., \& Carpenter, Z. L. (1980). Lysosomal enzyme distribution in electrically stimulated bovine muscle. Journal of Food Science, 45(3), 1097-1099. http://dx.doi.org/10.1111/j.1365-2621.1980. tb07533.x.

Dwinger, R. H., Golden, T. E., Hatakka, M., \& Chalus, T. (2008). Meat safety: regulatory aspects in the European Union. Meat Biotech, 4(2), 453-465. http://dx.doi.org/10.1007/978-0-387-79382-5_20.

Farias, L. R., Mendes, T. M. F. D. F., Panero, F. D. S., \& Satelles, J. L. (2018). Physical and chemical characterization of honey bees of some municip alities of state Roraima. Periódico Tchê Química, 15(29), 39-48.

Hope-Jones, M., Strydom, P. E., Frylinck, L., \& Webb, E. C. (2010). The efficiency of electrical stimulation to counteract the negative effects of $\beta$-agonists on meat tenderness of feedlot cattle. Meat Science,
86(3), 699-705. http://dx.doi.org/10.1016/j.meatsci.2010.06.008. PMid:20619545.

Kaimbaeva, L. A. (2008). Qualitative characteristics and chemical composition of red dear meat. Bul Agricult Sci Kaz, 9(1), 5-57.

Kaimbaeva, L. A., \& Uzakov, Y. M. (2015). The use of red deer meat and by-products in production of meat products. Meat Ind, 8(1), 40-43.

Kaimbaeva, L. A., \& Gurinovich, G. V. (2016). Study of autolytic changes in red deer meat and beef. Indian Journal of Science and Technology, 9(30), 1-8. http://dx.doi.org/10.17485/ijst/2016/v9i30/98747.

Krause, J., Tshidino, S. C., Ogawa, T., Watanabe, Y., Oosthuizen, V., Somai, B., Muramoto, K., \& Naudé, R. J. (2011). Purification and partial characterization of ostrich skeletal muscle cathepsin D and its activity during meat maturation. Meat Science, 87(3), 196-201. http://dx.doi.org/10.1016/j.meatsci.2010.10.009. PMid:21055883.

Kudryashov, L. S. (2007). Enzymes of muscle tissue and their properties. Meat Ind, 9(2), 18-21.

Kurchaeva, E. E., Manzhesov, V. I., Maksimov, I. V., Pashchenko, V. L., Churikova, S. Y., \& Glotova, I. A. (2018). Biotechnological approaches in processing of secondary raw materials of meat industry. Periódico Tchê Química, 15(30), 717-724.

Malysheva, E. S., \& Zhukov, V. M. (2013). Peculiarities of microstructural changes of the lean tissue of red deer females during the post-mortem period. Cattle Breed, 2(100), 82-84.

Malysheva, E. S., Zhukov, V. M. (2015). Histoarchitectonics of the skeletal muscle tissue of 217 animals during growth and autolysis. Barnaul: Publishing house of AGAU.

Nikiforova, A. P., Hanhalaeva, I. A., \& Hamaganova, I. V. (2011). Beef product development using the QFD method. Food Techn, Mark. Manag \& Res, 2(1), 26-28.

Panero, P. D. S., Panero, J. D. S., Panero, F. D. S., Guedes, R. G., De Faria, F. S. E. D. V., \& Rodriguez, A. F. R. (2018). Potential of near infrared spectroscopy-nir allied the multivariate analysis for geographical discrimination of buriti (mauritia flexuosa l.) amazonian oil. Periódico Tchê Química, 15(29), 113-122.

Rogov, I. A., Danilchuk, T. N., \& Abdrashitova, G. G. (2013). Structure at the nano level of fermented connective tissue of beef. Meat Ind, 6(1), 26-28.

Standard of Organisation. (2013). Federal State-Funded Educational Institution of Higher Profesional Education 00493184-001, Red deer meat. Method of histological examination. Iochkar-Ola: Russian Federation. 